\begin{tabular}{l|ll} 
J B E & $\mid \begin{array}{ll}\text { JOURNAL OF } \\
\text { BIOLOGY }\end{array}$ & $\begin{array}{l}\text { E-ISSN 2656-3436/ P-ISSN 2615-3947 } \\
\text { IAIN KUDUS } \\
\text { Tersedia online: http://journal.iainkudus.ac.id/index.php/jbe }\end{array}$ \\
\hline
\end{tabular}

\title{
Interaksi Kelembagaan dalam Pengelolaan dan Pemanfaatan Kawasan Ekologis Bentang Alam Karst Sukolilo di Kabupaten Pati
}

\author{
Wildansyah Firdaus Adiguna ${ }^{1}$, Hadi Wahyono ${ }^{2}$ \\ Dinas Pekerjaan Umum dan Penataan Ruang Kabupaten Pati ${ }^{1}$ \\ Departemen Perencanaan Wilayah dan Kota Universitas Diponegoro ${ }^{2}$ \\ wildansyahfirdausadiguna@gmail.com, hadi.wahyono@pwk.ft.undip.ac.id
}

\begin{abstract}
ABSTRAK
Kawasan karst memberikan perlindungan dalam menjaga keseimbangan alam maupun penyediaan simpanan air bersih. Hasil olahan citra landsat 8 tahun 2019, persentase vegetasi KBAK Sukolilo di Kabupaten Pati sebesar 27,96\%, Kabupaten Grobogan sebesar 36,16\%, vegetasi terbaik di Kabupaten Blora seluas 49,93\%. Kabupaten Pati memiliki persentase vegetasi paling rendah. Dampaknya, kawasan di bawahnya mengalami banjir akibat limpasan air dari pegunungan. Hal ini menjadi indikasi bahwa diperlukan optimalisasi kerjasama antar instansi dalam pengaturan regulasi. Penelitian ini bertujuan untuk menganalisis jejaring interaksi antar lembaga yang terkait dalam pengelolaan KBAK Sukolilo di Kabupaten Pati. Penelitian ini menggunakan metode kuantitatif dengan mengukur kepentingan dan pengaruh lembaga serta jejaring interaksi antar lembaga. Penentuan subjek penelitian melalui purposive sampling. Berdasarkan hasil penelitian, diperoleh 23 lembaga terlibat. Berdasarkan klasifikasi matriks kepentingan dan pengaruh diperoleh key players 4 lembaga; subject tidak ada lembaga terklasifikasi; context setters 4 lembaga; dan crowds 15 lembaga. Hubungan antar lembaga diperoleh mayoritas lembaga tidak menunjukkan adanya interaksi. Interaksi dipengaruhi beberapa faktor, diantaranya: komunikasi dan pertukaran informasi; sumber daya; pembagian peran; pengambilan keputusan; manfaat yang dihasilkan/diperoleh; komitmen; dan stuktur hierarki jaringan interaksi. Dapat disimpulkan bahwa interaksi antar lembaga dalam pengelolaan dan pemanfaatan KBAK Sukolilo di Kabupaten Pati belum mencapai kolaborasi kelembagaan, hanya jaringan kerja dan koordinasi.
\end{abstract}

Kata kunci: KBAK Sukolilo, Pati, lembaga, interaksi, peran 


\begin{abstract}
Karst area provides protection in maintaining the balance of nature and the provision of clean water deposits. Based of processed landsat 8 imagery in 2019. Percentage of vegetation in KBAK Sukolilo showed Pati Regency has 27,96\%, Grobogan Regency has 36,16\% and Blora Regency has the best vegetation with 49,93\%. Pati Regency has the lowest percentage of vegetation. It cause often affected by floods due to runoff water from hill to the below of area. This is an idication that optimization of cooperation between stakeholders is needed in regulating. The aim of this research is to analyze the interaction network between stakeholders in the management of Sukolilo Karst Area in Pati Regency. This research used quantitative approach. Determination of research subject trough purposive sampling. Based on the research results, 23 institutions were involved. Based on the classification of the interest and influence matrix, key players consisted of 4 institutions; no classified institution in subject; context setters consisted of 4 institutions; and crowds consisted of 15 institutions. Most institutions do not interact with each other. This interaction is influenced by several factors, including: communication and information exchange; resource; the division of roles; decision-making; the benefits generated/obtained; commitment; and the hierarchical structure of the interaction network. It can be concluded that the interaction between institutions in the management and utilization of Sukolilo Karst Area in Pati Regency has not achieved institutional collaboration, only the network of work and coordination.
\end{abstract}

Keywords: Sukolilo Karst Area, Pati, stakeholders, interaction, role

\title{
PENDAHULUAN
}

Kawasan karst menjadi salah satu potensi penting baik sumbangsih dalam ilmu pengetahuan maupun manfaat yang diperoleh bagi sisi sosial-ekonomi. Fungsi hidrologi kawasan karst memiliki peran yang sangat penting bagi kelangsungan hidup makhluk hidup. Berdasarkan Peraturan Pemerintah Nomor 26 Tahun 2008 tentang Rencana Tata Ruang Wilayah Nasional, kawasan karst memiliki keunikan/kekhasan sebagai kawasan lindung geologi yang merupakan salah satu kawasan lindung nasional. Kawasan lindung geologi merupakan kawasan yang memiliki fungsi utama sebagai fungsi melindungi lingkungan geologi di sekitarnya. Oleh karena itu, kawasan karst ini menjadi salah satu faktor dalam mendukung keberlanjutan makhluk hidup dan keanekaragaman hayati, terutama manusia dalam mempertahankan hidupnya.

Karst Sukolilo merupakan perbukitan kapur yang membentang di Pegunungan Kendeng Utara. Pegunungan Kendeng Utara terbentang mulai dari Kabupaten Kudus di Jawa Tengah hingga di Kabupaten Tuban di Jawa Timur. Berdasarkan Keputusan Menteri ESDM Nomor 2641 K/40/MEM/ 2014 tentang Penetapan Kawasan Bentang Alam Karst (KBAK) 
Sukolilo, kawasan ini memiliki luas 20.079 hektar yang meliputi 3 kabupaten yaitu Pati, Grobogan dan Blora. Kawasan karst ini memiliki peran yang sangat vital bagi wilayah di sekitar. Berdasarkan Keputusan Menteri ESDM tersebut, KBAK Sukolilo merupakan kawasan lindung geologi yang merupakan bagian dari kawasan lindung nasional. Selain sebagai habitat dengan keragaman biodiversitas, kawasan ini memiliki mata air dan sistem sungai di bawah tanah yang merupakan daerah penyimpan air untuk wilayah di Kabupaten Pati, Blora dan Grobogan (Wacana et al., 2011).

Namun meskipun ditetapkan sebagai kawasan lindung geologi, pemanfaatan ruang dan sumber daya di KBAK Sukolilo masih dilakukan secara sembarangan. Penambangan liar dan berkurangnya vegetasi tanaman keras berdampak pada kerusakan lingkungan dan bencana alam. Rusaknya vegetasi terjadi di sisi utara KBAK Sukolilo. Selain itu, bencana banjir juga sering terjadi di sisi utara KBAK Sukolilo akibat luapan sungai yang berhulu di Pegunungan Kendeng Utara ini. Wilayah yang terletak di sisi utara KBAK Sukolilo yaitu Kabupaten Pati yang dibentangi KBAK Sukolilo dari bagian tenggara hingga barat daya.

KBAK Sukolilo di Kabupaten Pati terletak di tiga kecamatan bagian selatan Kabupaten Pati, meliputi Kecamatan Sukolilo, Kayen dan Tambakromo. Berdasarkan Peraturan Daerah Kabupaten Pati Nomor 5 Tahun 2011 tentang Rencana Tata Ruang Wilayah Kabupaten Pati Tahun 2010-2030, kawasan ini diperuntukkan sebagai kawasan suaka alam dan kawasan strategis bidang fungsi dan daya dukung lingkungan. Kawasan ini memberikan perlindungan bagi kawasan di bawahnya, baik dalam menjaga keseimbangan alam maupun memberikan penyediaan simpanan air bersih bagi kawasan lain.

KBAK yang sebenarnya merupakan kawasan lindung geologi banyak dimanfaatkan sebagai tambang dan dibuka untuk pertanian. Kegiatan masyarakat yang ditemukan di kawasan ini adalah kegiatan penambangan batu kapur dan menggunakan kawasan hutan untuk bercocok tanam. Kegiatan penambangan sangat berpotensi terhadap kerusakan lingkungan. Akibat pembukaan lahan di kawasan karst akan berdampak pada polusi air, tanah dan udara; berkurangnya flora, fauna dan keanekaragaman hayati; erosi tanah dan tanah longsor; perubahan lansekap serta degradasi lahan pertanian (Ringo \& Mayengo, 2016; Lamare \& Singh, 2016). Salah satu permasalahan yang muncul ketika musim penghujan diantaranya banjir akibat luapan Sungai Juwana yang berhulu di wilayah ini. 
Luas kawasan hutan di 3 kecamatan tersebut selalu berkurang dalam 5 tahun terakhir. Berdasarkan olahan data Badan Pusat Statistik (BPS), dalam kurun 5 tahun terakhir terjadi penurunan hutan seluas $19,9 \%$. Hal ini apabila tidak dikendalikan akan semakin bertambah untuk tahun-tahun berikutnya. Pembukaan lahan sebagai lahan pertanian menjadi permasalahan lain, lahan yang seharusnya memiliki tutupan lahan berupa hutan digunakan sebagai lahan pertanian bagi masyarakat. Rusaknya ekosistem lingkungan di daerah tangkap dan belum adanya kesadaran masyarakat untuk tanggap terhadap bencana menyebabkan banjir bandang dan banjir genangan yang sering terjadi di wilayah Kabupaten Pati (Prayitno, 2017). Selain itu, tambang batu kapur juga sangat banyak ditemui di bukit-bukit yang ada di kawasan ini. Pembukaan lahan dan pemotongan bukit-bukit ini dapat menyebabkan rusaknya sistem cadangan air yang ada di daerah karst, karena hilangnya fungsi bukit sebagai penyimpan dan menyuplai air ke sungai bawah tanah akibat aktivitas pertambangan. Akibatnya, ketika musim kemarau tiba cadangan air tanah berkurang drastis dan di musim hujan, air akan melimpah hingga mengakibatkan banjir karena fluktuasi air sungai bawah tanah tidak terkendali. Upaya konservasi perlu dilakukan untuk mempertahankan fungsi ekologi, mengingat vitalnya ekosistem karst dan sumber daya alam yang tidak dapat diperbaharui (Tyas et al., 2016).

Permasalahan yang timbul ini menjadi indikasi bahwa perlu mengoptimalkan kerjasama antar instansi dalam upaya pelestarian, baik lingkup penataan ruang maupun penggunaan kewenangan tugas pokok dan fungsi dari lembaga. Pengelolaan KBAK Sukolilo di Kabupaten Pati ini setidaknya melibatkan berbagai instansi pemerintahan, swasta maupun masyarakat. Kepentingan dan pengaruh dari setiap lembaga dalam pengelolaan kawasan perlu dipetakan dengan jelas. Pengelolaan KBAK Sukolilo perlu juga melibatkan sektor swasta dan juga masyarakat. Untuk membantu pengelola bagaimana melibatkan pemangku kepentingan tersebut dalam pencapaian tujuan (Reed et al., 2009). Pemangku kepentingan yang dimaksud yaitu lembaga yang memiliki perhatian dan/atau dapat mempengaruhi hasil suatu kegiatan (Salam \& Noguchi, 2006).

Pengelolaan dan pemanfaatan KBAK Sukolilo di Kabupaten Pati melibatkan berbagai lembaga yang memiliki peran dan fungsi masing-masing. Peran dan fungsi dari berbagai lembaga ini dapat digambarkan dengan mengetahui tingkat kepentingan dan pengaruh 
masing-masing lembaga melalui pemetaan lembaga. Pemetaan lembaga ini dapat diketahui dengan melihat kerjasama antar lembaga, apakah antar lembaga bekerjasama dengan baik atau tidak (Reed et al., 2009). Masing-masing lembaga dapat berkolaborasi dalam pengelolaan dan pemanfaatan KBAK Sukolilo di Kabupaten Pati. Kolaborasi merupakan tingkat kerjasama dalam hal kerjasama tim, komunikasi dan pertimbangan dari berbagai pihak untuk mencapai tujuan bersama (Frey et al., 2006).

Ostrom dalam Amalia et al. (2019) menjelaskan, langkah penting untuk mengurai permasalahan tata kelola dapat melalui pemetaan tata kelola dan mengidentifikasi semua institusi yang berkecimpung. Selain itu, strategi pembatasan tugas dan pembuatan struktur kelembagaan perlu dirumuskan untuk pengelolaan di kawasan ini (Geir \& Vedeld, 2017). Diperlukan pengintegrasian tiga bidang dalam pengelolaan kelembagaan dalam penataan ruang, yaitu integrasi teritorial, kebijakan dan kelembagaan (Ran \& Nedovic-budic, 2016). Oleh karena itu, diperlukan pengelolaan yang baik dalam tata kelembagaan pada pengelolaan KBAK Sukolilo di Kabupaten Pati. Berdasarkan hal tersebut, rumusan masalah dapat dirumuskan dalam bentuk pertanyaan yaitu, "Seperti apa jejaring interaksi serta kapasitas dan mekanisme kerja kelembagaan dalam pengelolaan Kawasan Bentang Alam Karst Sukolilo di Kabupaten Pati?" dan "Mengapa interaksi antar lembaga dalam pengelolaan Kawasan Bentang Alam Karst Sukolilo di Kabupaten Pati ini terbentuk?”.

Interaksi kelembagaan dalam upaya pelestarian KBAK Sukolilo di Kabupaten Pati melibatkan banyak lembaga. Oleh karena itu, penelitian ini bertujuan untuk menganalisis jejaring interaksi antar lembaga yang terkait dalam pengelolaan Kawasan Bentang Alam Karst Sukolilo di Kabupaten Pati. Penelitian ini membahas mengenai lembaga yang berperan, tingkat kepentingan dari setiap lembaga serta interaksi antar lembaga yang terbentuk. Penelitian ini diharapkan dapat memberikan masukan dan evaluasi bagi pemangku kepentingan terkait dalam mewujudkan efektifitas interaksi kelembagaan dalam pengelolaan KBAK Sukolilo di Kabupaten Pati. 


\section{METODE PENELITIAN}

Penelitian ini menggunakan metode penelitian kuantitatif. Teknik pengumpulan data dilakukan dengan survei instansi dengan memberikan kuesioner dan telaah dokumen, observasi lapangan, serta wawancara. Penentuan narasumber menggunakan teknik purposive sampling pada lembaga-lembaga yang terlibat. Analisis yang digunakan dalam penelitian ini meliputi identifikasi lembaga serta peran, tugas pokok dan fungsi; pemetaan peran lembaga berdasarkan model analisis lembaga yang diperkenalkan oleh Reed et al. (2003); pemetaan hubungan lembaga berdasarkan pemetaan interaksi oleh Frey et al. (2006); dan analisis faktor-faktor penyebab tingkat interaksi.

\section{HASIL DAN PEMBAHASAN}

\section{Kondisi Fisik Alamiah KBAK Sukolilo}

Kawasan Bentang Alam Karst (KBAK) Sukolilo ditetapkan sebagai Kawasan lindung atau cagar budaya geologi oleh pemerintah melalui Kementerian Energi dan Sumber Daya Mineral (ESDM). Hal ini didasari karena keunikan komponen geologi diantaranya nilai-nilai ilmiah yang terkandung di dalam Kawasan tersebut. Kawasan karst ini menyimpan air tanah dan sebagai pengatur alami air tanah.

Mata air yang terdapat di kawasan ini merupakan mata air yang bersifat permanen, atau mampu mengalirkan air sepanjang musim dengan debit yang relatif tetap. Pemanfaatan kawasan karst selain sebagai penyimpan air tanah juga sebagai hutan produksi. Selain itu, banyak ditemukan gua-gua alam yang memiliki nilai potensi pariwisata.

Fungsi vital dari KBAK Sukolilo ini telah diperkuat dengan kebijakan dari pemerintah terkait. Kepmen ESDM Nomor 2641 K/40/MEM/2014 mengatur bahwa kawasan karst ini menjadi kawasan lindung atau cagar budaya geologi. Serta diatur dalam Peraturan Daerah Provinsi Jawa Tengah Nomor 16 Tahun 2019 tentang Perubahan Atas Peraturan Daerah Provinsi Jawa Tengah Nomor 6 Tahun 2010 tentang Rencana Tata Ruang Wilayah Provinsi Jawa Tengah Tahun 2009-2029 dan Peraturan Daerah Kabupaten Pati Nomor 2 Tahun 2021 tentang Perubahan Peraturan Daerah Kabupaten Pati Nomor 5 Tahun 2011 Tentang Rencana Tata Ruang Wilayah Kabupaten Pati Tahun 2010-2030. 


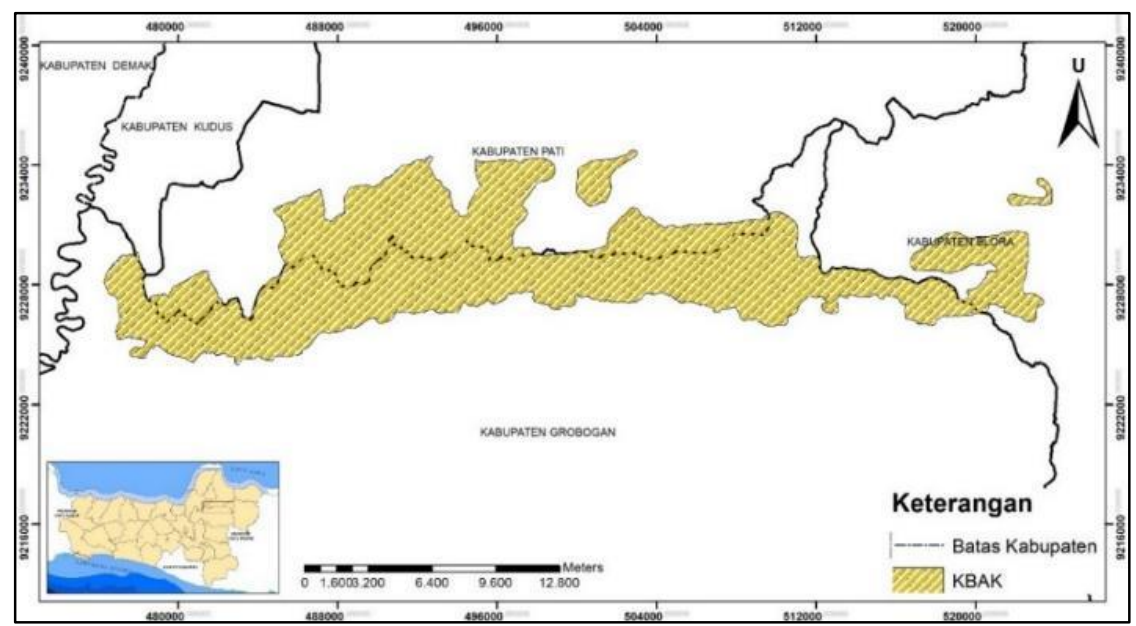

Sumber : Kepmen ESDM Nomor 2641 K/40/MEM/2014

Gambar 1. Peta Letak Geografis Kawasan Bentang Alam Karst Sukolilo

KBAK Sukolilo meliputi 3 kabupaten yaitu Kabupaten Pati, Kabupaten Grobogan, serta Kabupaten Blora. Kawasan ini memiliki luas 19.472 hektar, terdiri dari Kabupaten Pati seluas 11.802 ha, Kabupaten Grobogan seluas 7.217 ha dan Kabupaten Blora seluas 453 ha. Peta KBAK Sukolilo di ketiga kabupaten tersebut terlampir pada Gambar 1 di atas.

Masing-masing bagian KBAK Sukolilo ini memiliki kondisi vegetasi yang berbedabeda. Tutupan vegetasi di KBAK Sukolilo didominasi oleh hutan jati. Namun, kondisi vegetasi di ketiga kabupaten tersebut berbeda-beda. Pada Gambar 2 dan Tabel 1 memetakan terkait kondisi vegetasi di KBAK Sukolilo yang mencakup ketiga kabupaten. Pemetaan ini didasarkan dari hasil olahan citra landsat 8 pengambilan gambar November 2019. Berdasarkan data tersebut, dapat dilihat bahwa Kabupaten Grobogan memiliki luasan area KBAK Sukolilo yang paling luas. Sedangkan Kabupaten Blora memiliki luasan yang paling sempit. Apabila melihat kondisi vegetasi, Kabupaten Blora memiliki perbandingan luas area vegetasi yang paling baik dibandingkan dengan kedua kabupaten lain, dengan luas 49,93\% dari luas area karst. Kabupaten Pati memiliki persentase vegetasi yang paling kecil, dengan 27,96\% dari luas area karst di Pati. 


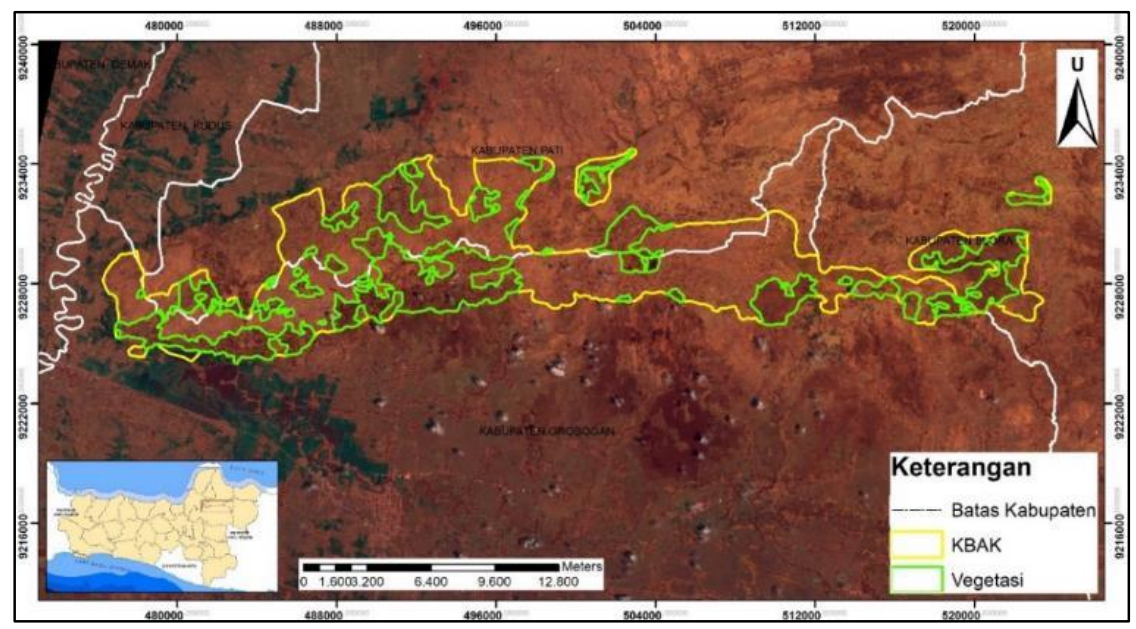

Sumber :Hasil Olahan Citra Landsat 8, 2021

Gambar 2. Peta Tutupan Vegetasi Kawasan Bentang Alam Karst Sukolilo

Tabel 1. Kondisi Vegetasi Kawasan Bentang Alam Karst Sukolilo

\begin{tabular}{cccc}
\hline Kabupaten & $\begin{array}{c}\text { Luas Area KBAK } \\
\text { (ha) }\end{array}$ & $\begin{array}{c}\text { Luas Vegetasi } \\
\text { (ha) }\end{array}$ & $\begin{array}{c}\text { Persentase Vegetasi } \\
(\%)\end{array}$ \\
\hline Grobogan & 11.220 & $4.057,45$ & 36,16 \\
\hline Pati & 7.180 & $2.007,88$ & 27,96 \\
\hline Blora & 1.679 & 838,35 & 49,93 \\
\hline
\end{tabular}

Sumber : Hasil Olahan Citra Landsat 8, 2021

\section{Identifikasi Lembaga, Peran, dan Tugas Pokok dan Fungsi}

Kegiatan pengelolaan dan pemanfaatan KBAK Sukolilo melibatkan banyak lembaga yang berasal dari berbagai instansi pemerintahan baik tingkat kabupaten, provinsi maupun instansi vertikal dari kementerian, Badan Usaha Milik Negara (BUMN), lembaga swasta baik organisasi profit maupun non profit serta kelompok masyarakat dan masyarakat. Untuk mengidentifikasi lembaga yang terlibat, digunakan pendekatan berdasarkan isu strategis dan pengamatan di lapangan. Terdapat 23 lembaga yang memiliki keterlibatan dalam pengelolaan maupun pemanfaatan KBAK Sukolilo. Lembaga ini terdiri dari instansi pemerintahan di kabupaten maupun provinsi, lembaga swasta dan juga kelompok masyarakat. Adapun lembaga yang terlibat adalah sebagai berikut: 
a. Instansi pemerintah

Peran instansi pemerintah yaitu sebagai regulator, baik usaha dalam perencanaan program pengembangan kawasan, penataan, pembinaan, pengawasan dan perlindungan sumber daya kawasan. Instansi pemerintah melakukan upaya konservasi lingkungan dan pemulihan ekosistem KBAK. Pengurangan risiko bencana juga dilakukan oleh instansi pemerintahan dalam mengelola KBAK Sukolilo.

Dalam upaya pengendalian lingkungan dan upaya pencegahan kerusakan lingkungan dikeluarkan regulasi-regulasi terkait pemanfaatan sumber daya di KBAK maupun kawasan sekitar KBAK Sukolilo. Instansi pemerintah memiliki peran dan wewenang dalam mengeluarkan surat izin maupun surat rekomendasi, baik terkait tata ruang, pemanfaatan kawasan hutan, izin lingkungan maupun izin pemanfaatan hasil hutan yang ada di KBAK Sukolilo. Dinas Energi dan Sumber Daya Mineral (ESDM) Provinsi Jawa Tengah, Dinas Lingkungan Hidup (DLH) Kabupaten Pati dan Dinas Pekerjaan Umum dan Penataan Ruang (DPUTR) Kabupaten Pati melakukan tindakan pencegahan pemanfaatan mineral dan batuan yang ada di KBAK Sukolilo, dan memberikan arahan pemanfaatan di lokasi yang tidak berada di kawasan tersebut. Selain itu, upaya penegakan hukum atas lokasi di KBAK Sukolilo juga dilaksanakan oleh instansi pemerintah, diantaranya kepolisian dan Satuan Polisi Pamong Praja.

Selain itu, upaya pemberdayaan masyarakat juga dilakukan oleh instansi pemerintah baik pusat, provinsi maupun kabupaten. Pemberdayaan masyarakat ini dilakukan melalui pembentukan kelompok sadar wisata dan sosialisasi kepada masyarakat terkait upaya pelestarian kawasan karst dan hutan di KBAK Sukolilo. Peran instansi pemerintah juga terkait penyediaan data dan informasi melalui inventarisasi data seluruh aspek yang ada dan mempublikasikannya ke media massa sehingga dapat diakses oleh masyarakat.

\section{b. Badan Usaha Milik Negara (BUMN)}

BUMN yang terlibat yaitu Perum Perhutani. Pemangku kepentingan kawasan hutan di Kabupaten Pati dikelola oleh Perum Perhutani Kesatuan Pemangkuan Hutan (KPH) Pati yang bergerak di bidang kehutanan dan memiliki wewenang dalam upaya pengelolaan sumber daya hutan. Berdasarkan PP Nomor 72 Tahun 2010 tentang Perusahaan Umum Perum Kehutanan Negara, Perhutani melaksanakan fungsi pelayanan bagi kemanfaatan 
umum dan memperoleh keuntungan dengan prinsip pengelolaan perusahaan dan kelestarian sumber daya hutan.

Selain melaksanakan tata usaha di bidang kehutanan, Perhutani juga melaksanakan kegiatan sosial di KBAK Sukolilo, diantaranya melakukan penghijauan di bentang alam karst ini. Kegiatan tersebut dilaksanakan bersama dengan Pemerintah Daerah Kabupaten Pati dan juga Kodim 0718/Pati. Kegiatan penghijauan ini dilaksanakan untuk mengembalikan dan merevitalisasi ekosistem hutan di KBAK Sukolilo.

c. Pelaku usaha

Kegiatan usaha yang dapat dilakukan di KBAK dan kawasan sekitar KBAK Sukolilo yaitu kegiatan usaha pertambangan yang dilakukan di luar kawasan sekitar KBAK. Kawasan karst merupakan kawasan lindung geologi, sehingga dilarang untuk dilakukan eksplorasi dan eksploitasi sumber daya alam berupa mineral dan batuan. Namun, pelaku tambang memiliki peran dalam pengembangan infrastruktur perdesaan dan pemberdayaan masyarakat pada lokasi bentang alam karst tersebut. Kegiatan ini merupakan bentuk Corporate Social Responsibility (CSR) dari pelaku tambang kepada masyarakat sekitar lokasi tambang.

d. Lembaga penelitian

Lembaga penelitian ini terdiri dari peneliti/akademisi, Non Governmental Organization (NGO) dan lembaga pers, peneliti/akademisi banyak melaksanakan kegiatan penelitian di KBAK Sukolilo, baik terkait ekologi maupun speleologi (ilmu yang mempelajari tentang gua dan lingkungannya) di KBAK Sukolilo. NGO melakukan penelitian terkait pelestarian ekologi karst dan pemberdayaan masyarakat. NGO juga menyediakan data terkait hasil penelitiannya kepada instansi pemerintahan sebagai bahan perumusan kebijakan. Lembaga pers memiliki peran sebagai media penyampaian informasi terkait KBAK Sukolilo sekaligus menjalankan fungsi kontrol dan pengawasan jalannya birokrasi dan diinformasikan kepada masyarakat.

e. Kelompok masyarakat

Kelompok masyarakat merupakan penduduk yang bertempat tinggal di lingkup kawasan yang dideleniasi sebagai KBAK Sukolilo. Masyarakat memiliki peran dalam menjaga kelestarian alam KBAK Sukolilo dan juga turut merasakan manfaat sumber daya 
di kawasan karst tersebut. Masyarakat memiliki pergerakan untuk turut menjaga kelestarian alam. Mereka sangat intensif melakukan kampanye pelestarian lingkungan di KBAK Sukolilo. Masyarakat juga turut memanfaatkan sumber daya alam berupa hasil pertanian dan perkebunan yang tumbuh subur di beberapa lokasi KBAK Sukolilo. Masyarakat juga memanfaatkan lahan perhutani untuk bercocok tanam. Hasil pertanian dan perkebunan yang banyak ditemukan di kawasan karst ini.

\section{Pemetaan Peran Lembaga}

Lembaga yang teridentifikasi pada analisis di atas memiliki tingkat pengaruh dan kepentingan masing-masing dalam pengelolaan dan pemanfaatan Kawasan Bentang Alam Karst (KBAK) Sukolilo. Tingkat kepentingan pada masing-masing lembaga dipengaruhi oleh keterlibatan dari masing-masing lembaga, manfaat yang diperoleh dari kegiatan pengelolaan maupun pemanfaatan KBAK Sukolilo, program kerja, kesediaan partisipasi dari lembaga, serta kesesuaian tupoksi masing-masing lembaga dalam pengelolaan maupun pemanfaatan KBAK Sukolilo. Tingkat pengaruh pada masing-masing lembaga dipengaruhi oleh pengaruh wewenang masing-masing lembaga, tindakan dalam program usaha pengelolaan dan pemanfaatan KBAK Sukolilo, penguasaan sumberdaya strategis, bentuk keahlian masing-masing lembaga, dan pengaruh lembaga untuk keberlanjutan pengelolaan dan pemanfaatan KBAK Sukolilo. 


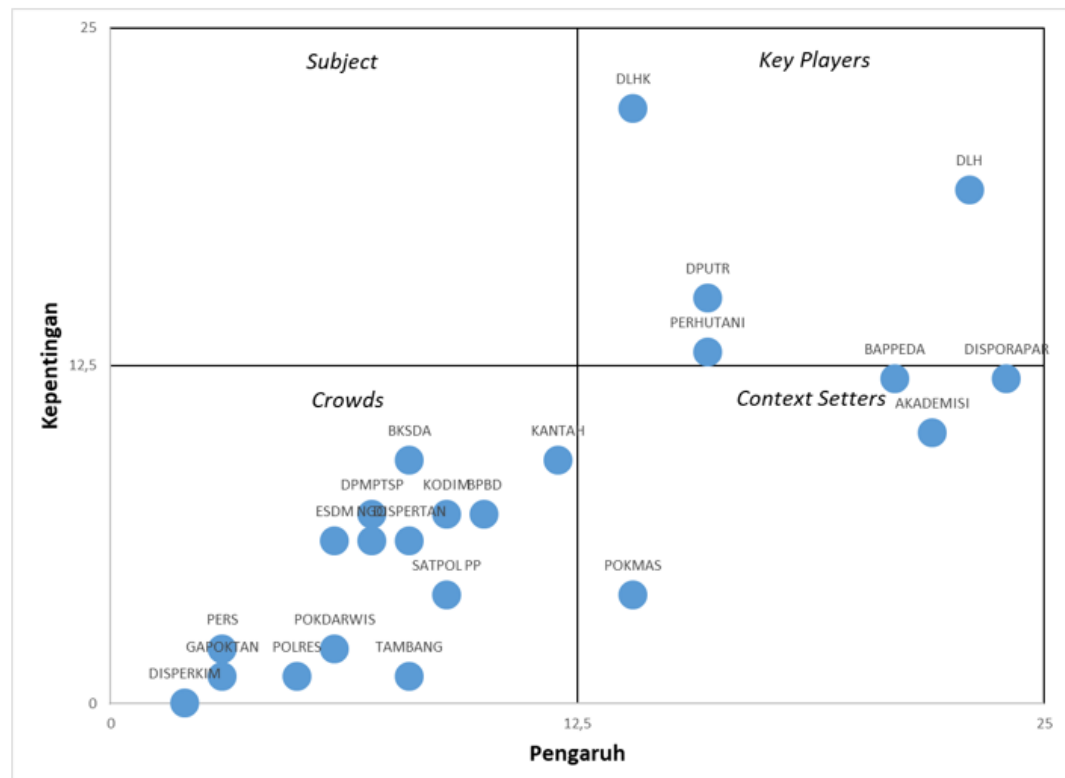

Keterangan: lembaga/institusi dalam pengelolaan dan pemanfaatan KBAK Sukolilo terdiri atas: Kantor Pertanahan
Kabupaten Pati (KANTAH); Balai Konservasi Sumber Daya Alam Provinsi Jawa Tengah (BKSDA); Kepolisian Resor
Pati (POLRES); Komando Distrik Militer 0718/Pati (KODIM); Dinas Energi Sumber Daya dan Mineral Provinsi Jawa
Tengah (ESDM); Dinas Lingkungan Hidup dan Kehutanan Provinsi Jawa Tengah (DLHK); Perum Perhutani
(PERHUTANI); Badan Perencanaan dan Pembangunan Daerah Kabupaten Pati (BAPPEDA); Dinas Pekerjaan Umum dan
Penataan Ruang Kabupaten Pati (DPUTR); Dinas Lingkungan Hidup Kabupaten Pati (DLH); Dinas Pertanian Kabupaten
Pati (DISPERTAN); Dinas Penanaman Modal dan Pelayanan Terpadu Satu Pintu Kabupaten Pati (DPMPTSP); Dinas
Perumahan dan Kawasan Permukiman Kabupaten Pati (DISPERKIM); Dinas Kepemudaan, Olahraga dan Pariwisata
Kabupaten Pati (DISPORAPAR); Satuan Polisi Pamong Praja Kabupaten Pati (SATPOLPP); Badan Penanggulangan
Bencana Daerah Kabupaten Pati (BPBD); Non Governmental Organization (NGO); Lembaga Pers (PERS); Pelaku
Pertambangan (TAMBANG); Akademisi/Lembaga Penelitian (AKADEMISI); Kelompok Sadar Wisata (POKDARWIS);
Gabungan Kelompok Tani (GAPOKTAN); Masyarakat/Kelompok Masyarakat Sekitar KBAK Sukolilo (POKMAS)

Sumber:Hasil analisis, 2020

Gambar 3. Matrik Tingkat Kepentingan Antar Lembaga pada Pengelolaan dan Pemanfaatan

Kawasan Bentang Alam Karst Sukolilo di Kabupaten Pati

Analisis kepentingan dan pengaruh masing-masing lembaga dalam pengelolaan dan pemanfaatan KBAK Sukolilo disajikan menggunakan matriks pada Gambar 3. Pada matriks tersebut menjelaskan mengenai pembagian 4 (empat) kelompok lembaga/institusi menjadi key player, subject, crowd dan context setter. Dari masing-masing kelompok tersebut memiliki jumlah lembaga yang berbeda tergantung pada tingkat kepentingan dan pengaruhnya. Lembaga yang menempati kuadran I dikategorikan sebagai key player, yaitu lembaga-lembaga yang memiliki nilai kepentingan dan pengaruh yang tinggi pada pengelolaan dan pemanfaatan KBAK Sukolilo. Lembaga-lembaga yang menempati kuadran II dikategorikan sebagai context setter, yaitu lembaga-lembaga yang memiliki kepentingan yang tinggi tetapi nilai pengaruh yang rendah. Pada kuadran III dikategorikan sebagai crowd, yaitu lembaga yang memiliki kepentingan dan pengaruh yang rendah. Sedangkan pada 
Kuadran IV dikategorikan sebagai subjects, yaitu lembaga yang memiliki nilai pengaruh yang tinggi dan memiliki kepentingan yang rendah.

a. Key players (pelaku kunci)

Key players memiliki peran penting dan memiliki pengaruh besar dalam pengelolaan dan keberlanjutan kawasan karst. Program yang dilakukan oleh lembaga yang dikategorikan dalam key player berupa kegiatan konservasi kawasan serta perlindungan dari kerusakan keunikan geologi di KBAK Sukolilo. Lembaga yang ada memiliki tanggung jawab dalam melakukan pengawasan maupun perkembangan kawasan.

b. Subject (subjek)

Subject memiliki peran yang bersifat suportif dengan kapasitas peluang untuk mengubah situasi yang kecil. Subject memiliki kepentingan yang besar namun memiliki pengaruh yang kecil. Dalam pengelolaan dan pemanfaatan KBAK Sukolilo, tidak ada lembaga yang dikategorikan menjadi subject. Tidak adanya lembaga dimungkinkan karena pada upaya pengelolaan dan pemanfaatan KBAK Sukolilo di Kabupaten Pati ini tidak ditemukan lembaga yang hanya memiliki fokus pada upaya konservasi kawasan.

c. Context setter (penyusun konteks)

Context setters terdiri dari lembaga/institusi yang memiliki pengaruh besar namun kepentingannya kecil. Pada kuadran ini, lembaga yang terklasifikasi memiliki wewenang dalam memengaruhi kebijakan, namun hanya bersifat saran yang tidak bersifat intervensi. d. Crowds (penonton)

Crowd merupakan lembaga/institusi yang memiliki kepentingan dan pengaruh yang rendah. Lembaga-lembaga ini tidak terlalu memiliki peran penting dalam upaya pelestarian KBAK Sukolilo di Kabupaten Pati.

\section{Pemetaan Hubungan Lembaga dalam Pengelolaan dan Pemanfaatan KBAK Sukolilo di Kabupaten Pati}

Hubungan antar lembaga dalam pengelolaan dan pemanfaatan KBAK Sukolilo diidentifikasi untuk mengetahui keterkaitan serta tingkat interaksi dari masing-masing lembaga yang terlibat. Hubungan antar lembaga dianalisis berdasarkan hasil wawancara dengan informan kunci yang ada di lapangan, sehingga dapat menjelaskan hubungan antar lembaga dalam pengelolaan dan pemanfaatan KBAK Sukolilo. Hubungan antar lembaga ini 
selanjutnya dipetakan berdasarkan interaksi antar lembaga-lembaga yang terlibat dalam pengelolaan dan pemanfaatan KBAK Sukolilo. Masing-masing kelompok akan dilihat hubungannya berdasarkan informasi, sumber daya, peran, komunikasi dan pengambilan keputusan. Hubungan antar lembaga ini dikelompokkan dalam beberapa jenis hubungan yang dapat dilihat pada Tabel 2 berikut.

Tabel 2. Penentuan Skor, Jenis Hubungan dan Penjelasan Hubungan

\begin{tabular}{|c|c|c|}
\hline Jenis Hubungan & Penjelasan Hubungan & Karakteristik Hubungan \\
\hline $\begin{array}{l}\text { Tidak } \\
\text { Berinteraksi } \\
\text { (Coexistence) }\end{array}$ & $\begin{array}{l}\text { Keduanya ada tetapi tidak ada } \\
\text { komunikasi }\end{array}$ & $\begin{array}{l}\text { - tidak saling bertukar informasi; } \\
\text { - tidak saling berbagi sumber daya; } \\
\text { - tidak saling berperan; } \\
\text { - tidak ada komunikasi; dan } \\
\text { - } \text { semua keputusan diambil secara independen. }\end{array}$ \\
\hline $\begin{array}{l}\text { Jaringan Kerja } \\
\text { (Networking) }\end{array}$ & $\begin{array}{l}\text { Keberadaannya disadari, } \\
\text { sedikit ada komunikasi, peran } \\
\text { tidak pasti, semua keputusan } \\
\text { dibuat sendiri-sendiri }\end{array}$ & $\begin{array}{l}\text { - } \text { saling menukar informasi untuk saling } \\
\text { menguntungkan; } \\
\text { - } \text { tidak perlu saling berbagi sumber daya; } \\
\text { - } \text { peran tidak mengikat; } \\
\text { - } \text { tingkat komunikasi dan kepercayaan rendah; } \\
\text { dan } \\
\text { - } \text { semua keputusan diambul secara independen. }\end{array}$ \\
\hline $\begin{array}{l}\text { Kerja Sama } \\
\text { (Cooperation) }\end{array}$ & $\begin{array}{lr}\text { Saling } & \text { memberikan } \\
\text { informasi, } & \text { terdapat } \\
\text { komunikasi formal dan } \\
\text { informal, peran sedikit } \\
\text { jelas/pasti, semua keputusan } \\
\text { dibuat sendiri-sendiri }\end{array}$ & $\begin{array}{l}\text { - } \text { saling menyediakan informasi; } \\
\text { - } \text { berbagi sumber daya tingkat sedang; } \\
\text { - pembagian peran agak jelas; } \\
\text { - } \text { komunikasi formal/resmi; dan } \\
\text { - } \text { semua keputusan diambil secara independen } \\
\text { dan ada penyesuaian kegiatan. }\end{array}$ \\
\hline $\begin{array}{l}\text { Koordinasi } \\
\text { (Coordination) }\end{array}$ & $\begin{array}{l}\text { Saling berbagi informasi dan } \\
\text { sumber daya, intensitas } \\
\text { komunikasi sering, peran } \\
\text { sudah jelas/pasti, sebagian } \\
\text { keputusan dibuat bersama- } \\
\text { sama }\end{array}$ & $\begin{array}{l}\text { - saling berbagi informasi; } \\
\text { - akses terhadap sumber daya lebih mudah; } \\
\text { - peran telah ditentukan dengan jelas; } \\
\text { - } \text { sering berkomunikasi secara intensif; dan } \\
\text { - } \text { beberapa keputusan diambil secara bersama- } \\
\text { sama dan ada penyesuaian kegiatan. }\end{array}$ \\
\hline
\end{tabular}




\begin{tabular}{|c|c|c|}
\hline Jenis Hubungan & Penjelasan Hubungan & Karakteristik Hubungan \\
\hline $\begin{array}{l}\text { Koalisi } \\
\text { (Coalition) }\end{array}$ & $\begin{array}{l}\text { Berbagi pendapat/gagasan } \\
\text { dan sumber daya, sering } \\
\text { berkomunikasi } \\
\text { diutamakan, pengambilan } \\
\text { keputusan diambil secara } \\
\text { bersama oleh semua anggota }\end{array}$ & $\begin{array}{l}\text { - } \text { saling berbagi informasi dan ide; } \\
\text { - } \text { saling berbagi sumber daya; } \\
\text { - } \text { peran telah ditentukan dengan jelas; } \\
\text { - } \text { sering berkomunikasi secara intensif dan } \\
\text { diprioritaskan; dan } \\
\text { - } \text { semua anggota memiliki suara dalam } \\
\text { pengambilan keputusan. }\end{array}$ \\
\hline $\begin{array}{l}\text { Kolaborasi } \\
\text { (Collaboration) }\end{array}$ & $\begin{array}{l}\text { Memiliki suatu sistem antar } \\
\text { anggota, komunikasi yang } \\
\text { kuat dan saling memiliki } \\
\text { kepercayaan, semua } \\
\text { keputusan dicapai melalui } \\
\text { konsensus }\end{array}$ & $\begin{array}{l}\text { - saling berbagi informasi serta meningkatkan } \\
\text { kapasitas masing-masing anggota; } \\
\text { - } \text { berbagi penuh sumber daya dan risiko; } \\
\text { - peran telah ditentukan dengan jelas dan } \\
\text { berada dalam satu sistem; dan } \\
\text { - } \text { sering berkomunikasi secara intensif dan } \\
\text { saling percaya. }\end{array}$ \\
\hline $\begin{array}{l}\text { Penyatuan } \\
\text { (Coadunation) }\end{array}$ & $\begin{array}{l}\text { Tumbuh secara bersama- } \\
\text { sama }\end{array}$ & $\begin{array}{l}\text { - } \text { saling berbagi informasi dan saling } \\
\text { meningkatkan kapasitas masing-masing } \\
\text { anggota; } \\
\text { - } \text { saling berbagi penuh sumber daya dan risiko; } \\
\text { - } \text { telah berada dalam satu sistem dan struktur } \\
\text { tersendiri yang terintegrasi dengan peran } \\
\text { yang terbagi dengan jelas; } \\
\text { - } \text { komunikasi intensif dengan tingkat } \\
\text { kepercayaan yang tinggi; } \\
\text { - keputusan dan kebijakan disepakati secara } \\
\text { konsensus. }\end{array}$ \\
\hline
\end{tabular}

Sumber: Frey et al, 2006

Pemetaan hubungan lembaga ini merupakan gambaran dari kondisi hubungan antar lembaga di lapangan. Hubungan antar lembaga dinilai berdasarkan indikator/parameter yang telah ditentukan serta berdasarkan hasil pengamatan di lapangan. Hubungan antar lembaga digambarkan dalam matriks yang dikategorikan berdasarkan skor jenis hubungan. Sehingga, 
hubungan antar lembaga tersebut dapat diketahui sebagaimana tertuang dalam Gambar 4 di bawah.

Berdasarkan hasil pemetaan interaksi kelembagaan dalam pengelolaan dan pemanfaatan KBAK Sukolilo yang telah dilakukan, ditemukan bahwa Badan Perencanaan Pembangunan Daerah (Bappeda) Kabupaten Pati memiliki berinteraksi dengan semua lembaga yang terlibat. Hal ini disebabkan karena Bappeda Pati memiliki fungsi sebagai instansi perencanaan pembangunan di daerah, sehingga memiliki intensitas interaksi antar lembaga yang besar. Dinas Penanaman Modal dan Pelayanan Terpadu Satu Pintu (DPMPTSP) Kabupaten Pati dan Dinas Lingkungan Hidup dan Kehutanan (DLHK) Provinsi Jawa Tengah memiliki interaksi terbanyak setelah Bappeda Kabupaten Pati dengan 21 interaksi. Dinas Perumahan dan Kawasan Permukiman (Disperkim) Kabupaten Pati memiliki interaksi yang paling sedikit dengan lembaga lain, sebesar 2 interaksi, dan Kepolisian Resor Pati memiliki 3 interaksi dengan lembaga lain.

Berdasarkan jenis interaksi, sebanyak 30,5\% dari hubungan antar lembaga yang terlibat tidak saling berinteraksi. Sebanyak 23,96\% berinteraksi dengan bentuk koordinasi, sedangkan sebanyak 20,2\% interaksi lembaga membentuk jaringan kerja. Bentuk interaksi berupa kerja sama dan kolaborasi berjumlah sama, yaitu sebesar 9,5\% dari jumlah seluruh interaksi, sedangkan bentuk interaksi penyatuan sebesar 3,96\%. Jumlah interaksi paling kecil dari seluruh bentuk interaksi lembaga dalam pengelolaan dan pemanfaatan KBAK Sukolilo di Kabupaten Pati yaitu berbentuk koalisi, sebesar 2,38\%.

Interaksi yang terbentuk didominasi dalam bentuk koordinasi dan jaringan kerja. Pola interaksi belum mencapai kolaborasi maupun koadunasi, hal ini dipengaruhi karena antar lembaga masih belum menjalin komunikasi intensif dan tidak saling bertukar informasi. Selain itu, antar lembaga belum saling berbagi sumber daya, sehingga keputusan belum diambil secara independen. Antar lembaga masih belum menjalin komitmen dan kepercayaan. Rekapitulasi jumlah interaksi antar lembaga dalam pengelolaan dan pemanfaatan KBAK Sukolilo di Kabupaten Pati dapat dilihat pada Tabel 3 berikut. 


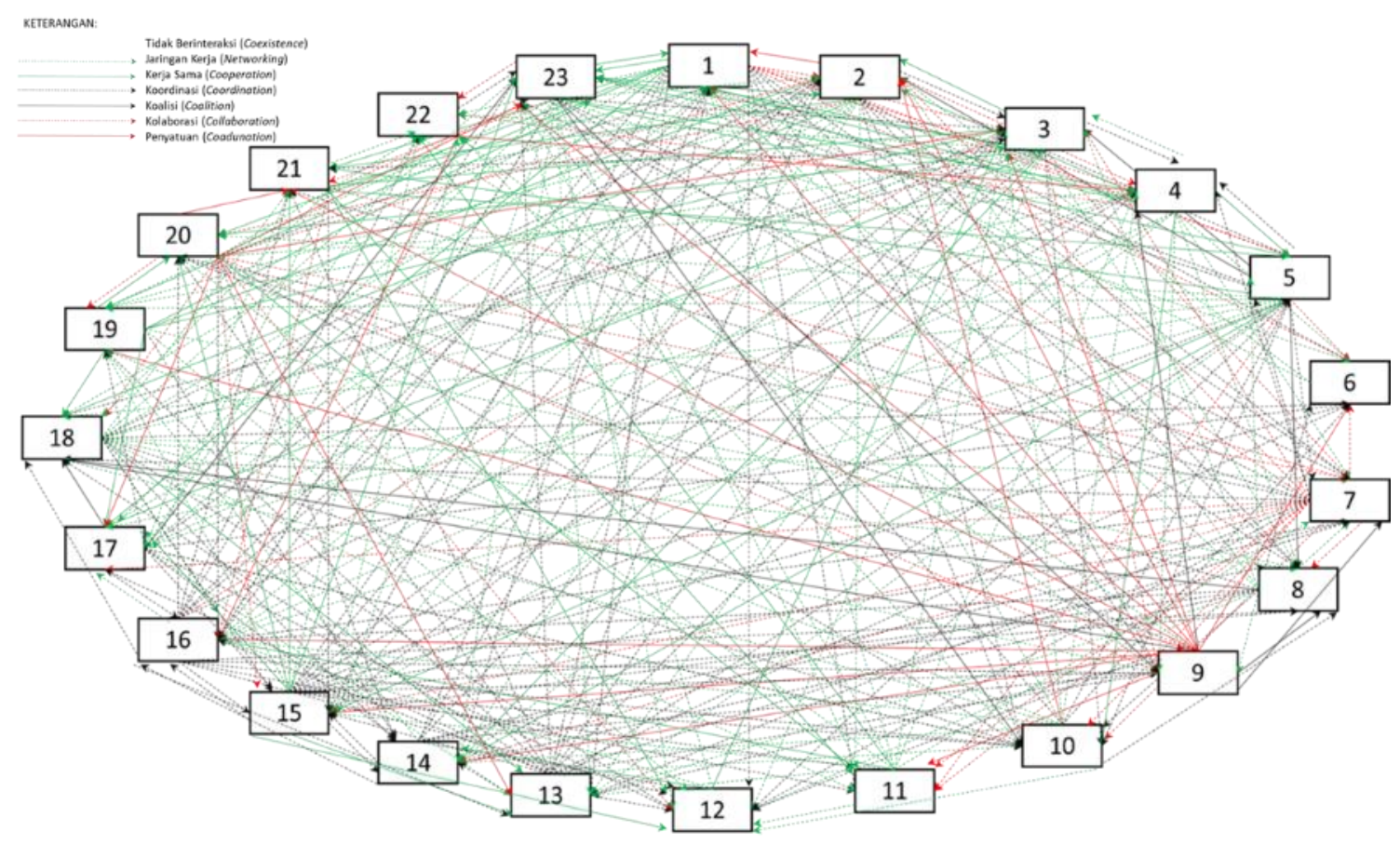

Sumber: Hasil Analisis, 2020

Gambar 4. Peta Interaksi Kelembagaan dalam Pengelolaan dan Pemanfaatan

KBAK Sukolilo di Kabupaten Pati

Tabel 3. Rekapitulasi Hubungan Antar Lembaga dalam Pengelolaan dan Pemanfaatan

KBAK Sukolilo di Kabupaten Pati

\begin{tabular}{lll} 
No & Interaksi & Jumlah \\
\hline 1 & Tidak berinteraksi (Coexistence) & 154 \\
\hline 2 & Jaringan kerja (Networking) & 102 \\
\hline 3 & Kerja sama (Cooperation) & 48 \\
\hline 4 & Koordinasi (Coordination) & 121 \\
\hline 5 & Koalisi (Coalition) & 12 \\
\hline 6 & Kolaborasi (Collaboration) & 48 \\
\hline 7 & Penyatuan (Coadunation) & 20 \\
Sumber: Hasil Analisis, 2021
\end{tabular}

Berdasarkan hubungan interaksi antar lembaga tersebut, diperoleh bahwa belum terjadi kolaborasi antara lembaga-lembaga yang terlibat dalam pengelolaan dan pemanfaatan KBAK Sukolilo di Kabupaten Pati. Tingkat interaksi yang terjadi antar pihak berbentuk 
jaringan kerja dan koordinasi. Interaksi yang terbentuk dalam jaringan kerja berupa saling tukar menukar informasi antara pihak yang saling berhubungan, namun dengan tingkat komunikasi dan kepercayaan yang masih rendah. Interaksi yang terbentuk pada koordinasi selain telah saling berbagi informasi, juga saling berbagi peran yang jelas dan telah terjalin komunikasi secara intensif serta saling memiliki kepercayaan antar pihak yang saling berinteraksi. Beberapa keputusan telah diambil secara bersama-sama dan telah membentuk suatu kegiatan bersama untuk mencapai suatu tujuan dalam pengelolaan dan pemanfaatan KBAK Sukolilo di Kabupaten Pati.

\section{Faktor-Faktor yang Memengaruhi Hubungan Lembaga dalam Pengelolaan dan Pemanfaatan KBAK Sukolilo di Kabupaten Pati}

Hubungan antar lembaga dalam pengelolaan dan pemanfaatan KBAK Sukolilo di Kabupaten Pati dipengaruhi oleh berbagai kondisi yang ada di antara kedua belah pihak yang saling berhubungan. Beberapa faktor yang memengaruhi interaksi tersebut dikaji melalui analisis deskriptif kualitatif berdasarkan kondisi yang ada di lapangan. Berikut faktor-faktor yang memengaruhi hubungan antar lembaga dalam pengelolaan dan pemanfaatan KBAK Sukolilo di Kabupaten Pati:

a. Komunikasi dan pertukaran informasi

Komunikasi dan akses pertukaran informasi yang mudah dapat memberikan kemudahan bagi interaksi antar lembaga. Kemudahan komunikasi dan akses informasi dapat saling mudah bertukar apabila ada kedekatan antara satu lembaga dengan lembaga yang lain yang cukup intensif saling berhubungan. Komunikasi yang baik, akan memengaruhi implementasi suatu kebijakan. Informasi yang akan disampaikan dari suatu kebijakan dapat diterima maksud dan tujuannya dengan baik. Pada level tertinggi, antar lembaga yang terlibat dapat saling berbagi informasi dan saling meningkatkan kapasitas.

b. Sumber daya

Sumber daya manusia maupun pendanaan menjadi faktor yang memengaruhi interaksi antar lembaga. Sumber daya manusia dilihat dari kemampuan/kompetensi dari personil di setiap lembaga yang mengetahui tugas dan peran masing-masing lembaga, sedangkan sumber daya pendanaan dilihat dari anggaran pembiayaan yang ditujukan untuk kegiatan 
dalam bentuk pelestarian/konservasi atau kegiatan pemanfaatan untuk memanfaatkan sumber daya alam yang ada di KBAK Sukolilo maupun di sekitarnya.

c. Pembagian peran

Peran dari masing-masing lembaga dapat memengaruhi interaksi. Peran yang terdefisini secara jelas dalam pengelolaan maupun pemanfaatan KBAK Sukolilo di Kabupaten Pati dapat meningkatkan interaksi hingga timbul upaya untuk saling berkolaborasi. Pada pelaksanaannya, pembagian peran ini sudah terbagi dengan jelas, dan terlihat pihak yang ingin melestarikan ekosistem di KBAK Sukolilo dan juga pihak yang ingin memanfaatkan sumber daya alam di KBAK Sukolilo. Pihak yang berfokus pada upaya pelestarian saling berinteraksi untuk mencapai tujuan yang sama.

d. Pengambilan keputusan

Pengambilan keputusan memengaruhi suatu interaksi apakan terbentuk kolaborasi atau bukan. Terdapat sebuah forum yang berisi Organisasi Pemerintah Daerah (OPD) di Kabupaten Pati bernama forum Tim Koordinasi Penataan Ruang Daerah (TKPRD), terkait dengan penataan ruang memutuskan kebijakan terhadap suatu kasus. Keputusan dan kebijakan tersebut disepakati secara konsensus oleh lembaga yang terlibat. Namun, untuk lembaga yang tidak termasuk dalam anggota TKPRD hal ini belum terbentuk, sehingga pengambilan keputusan masih berdasarkan keputusan setiap lembaga.

e. Jenis manfaat yang dihasilkan/diperoleh

Kedua belah pihak saling memperoleh manfaat, maka interaksi yang ditimbulkan menjadi lebih besar. Apabila hanya satu pihak yang merasa memperoleh keuntungan, maka akan terbentuk interaksi satu arah atau dua arah namun dalam skala kecil.

f. Komitmen dan kepercayaan

Komitmen dan kepercayaan yang kurang dalam berinteraksi dapat menyebabkan tidak dapat mencapai tujuan yang ingin dicapai dalam pelestarian KBAK Sukolilo. Pada pelaksanaannya, pihak yang akan memanfaatkan sumber daya alam di KBAK Sukolilo wajib untuk mengurus beberapa dokumen terkait upaya konservasi kawasan, seperti kesesuaian dengan tata ruang dalam hal ini apabila kegiatan tambang tidak berada di kawasan bentang alam karst, apabila kegiatan pariwisata besedia untuk menjaga keunikan 
alam dan juga tidak merusak bentang alam yang ada. Selain itu dokumen pengelolaan lingkungan wajib disusun untuk menjamin upaya pengelolaan lingkungan.

g. Struktur jaringan

Jaringan yang terbentuk saat ini membentuk hierarki yang didominasi oleh lembaga pemerintahan. Lembaga pemerintahan lebih berperan sebagai regulator dan juga berupaya untuk melindungi eksploitasi sumber daya yang ada. Sedangkan lembaga lain di luar lembaga pemerintahan kurang begitu terlihat dalam struktur jaringan interaksi.

\section{SIMPULAN}

KBAK Sukolilo ditetapkan melalui Keputusan Menteri ESDM No. 0398 K/40/MEM/2005 tentang Penetapan Kawasan Karst Sukolilo yang kemudian dicabut dan digantikan dengan Keputusan Menteri ESDM No. 2641 K/40/MEM/2014 tentang Penetapan Kawasan Bentang Alam Karst Sukolilo dan diperkuat dengan penetapan sebagai kawasan lindung geologi pada Peraturan Daerah tentang Rencana Tata Ruang Wilayah baik di Provinsi Jawa Tengah maupun di Kabupaten Pati. Pengelolaan dan pemanfaatan KBAK Sukolilo di Kabupaten Pati melibatkan banyak lembaga multisektor baik lembaga tingkat pusat, Organisasi Pemerintah Daerah (OPD) di tingkat provinsi dan kabupaten, BUMN, swasta maupun masyarakat. Pada penelitian ini, teridentidikasi 23 (dua puluh tiga) lembaga, yaitu 4 (empat) instansi vertikal pemerintah pusat, 2 (dua) OPD tingkat Provinsi Jawa Tengah, 9 (Sembilan) OPD tingkat Kabupaten Pati, 1 (satu) BUMN, 3 (tiga) lembaga swasta, 1 (satu) lembaga penelitian, 3 (tiga) lembaga berbasis masyarakat.

Lembaga yang terlibat dalam pengelolaan dan pemanfaatan KBAK Sukolilo yang teridentifikasi dikelompokkan ke dalam matriks berdasarkan kepentingan dan pengaruh terdiri dari : a) key players (pelaku kunci) terdiri dari 4 lembaga; b) subject (subjek) tidak ada lembaga yang terklasifikasi; c) context setters (penyusun konteks) terdiri dari 4 lembaga; dan d) crowds (penonton) terdiri dari 15 lembaga. Hubungan antar lembaga yang terlibat ini diperoleh bahwa sebagian besar tidak terjadi interaksi, yaitu sebesar 30,5\% dari keseluruhan interaksi, sedangkan sebanyak 23,96\% atau sebesar 121 interaksi berupa koordinasi, sebanyak 102 interaksi atau 20,2\% berinteraksi membentuk jaringan kerja, bentuk interaksi berupa kerja sama dan kolaborasi terbentuk sejumlah sama yaitu sebanyak 48 interaksi atau 
9,5\%, sebanyak 3,96\% atau 20 interaksi berupa penyatuan, sedangkan sisanya yaitu 12 interaksi atau sebesar 2,38\% berupa interaksi berbentuk koalisi. Berdasarkan hubungan interaksi antar lembaga tersebut, diperoleh bahwa belum terjadi kolaborasi antara lembagalembaga yang terlibat dalam pengelolaan dan pemanfaatan KBAK Sukolilo di Kabupaten Pati. Hal ini dipengaruhi karena antar lembaga masih belum menjalin komunikasi intensif dan tidak saling bertukar informasi. Selain itu, antar lembaga belum saling berbagi sumber daya, sehingga keputusan belum diambil secara independen. Antar lembaga masih belum menjalin komitmen dan kepercayaan.

Beberapa faktor yang memengaruhi interaksi antar lembaga ini disebabkan oleh: a) komunikasi dan pertukaran informasi; b) sumber daya manusia dan pembiayaan; c) pembagian peran; d) upaya pengambilan keputusan; d) jenis manfaat yang dihasilkan/diperoleh; e) komitmen dan kepercayaan; dan f) stuktur hierarki jaringan interaksi lembaga. Beberapa faktor dominan yang memengaruhi interaksi antar lembaga yaitu komunikasi dan pertukaran informasi, sumber daya, upaya pengambilan keputusan dan komitmen dan kepercayaan. Berdasarkan pernyataan-pernyataan di atas, dapat diketahui bahwa interaksi antar pihak dalam pengelolaan dan pemanfaatan KBAK Sukolilo di Kabupaten Pati berbentuk jaringan kerja dan koordinasi. Untuk pengembangan bidang keilmuan selanjutnya, terdapat beberapa rekomendasi yang dapat menjadi preferensi penelitian, antara lain kajian interaksi lembaga dalam pengelolaan dan pemanfaatan KBAK Sukolilo dengan studi kasus pada 3 kabupaten; kajian kerja sama antar daerah dalam pengelolaan KBAK Sukolilo; dan studi tata kelola pemerintahan terhadap jejaring kerjasama dan interaksi antar lembaga pada pengelolaan KBAK Sukolilo.

\section{DAFTAR PUSTAKA}

Amalia, W., Samekto, A., \& Prihatin, E. S. (2016). Perlindungan Hukum Kawasan Karst terhadapp Kegiatan Pertambangan Kaitannya dengan Pengelolaan Lingkungan (Studi Kasus Penambangan Batu Gamping di Kawasan Karst Gombong Selatan, Kebumen, Jawa Tengah). Jurnal Law Reform, 12(1), 132-144.

Frey, B. B., Lohmeier, J. H., Lee, S. W., \& Tollefson, N. (2006). Measuring Collaboration Among Grant Partners. American Journal of Evaluation, 27(3), 383-392. http://doi.org/10.1177/1098214006290356.

Geir, J., \& Vedeld, P. (2017). Rhetoric and reality in protected area governance: 
Institutional change under different conservation discourses in Mount Elgon National. Ecological Economics, 131, 166-177. http://doi.org/10.1016/j.ecolecon.2016.08.028.

Keputusan Menteri Energi dan Sumber Daya Mineral Nomor 2641 K/40/MEM/2014 Tentang Penetapan Kawasan Bentang Alam Karst Sukolilo.

Lamare, R. E., \& Singh, O. P. (2016). Limestone Mining and Its Environmental Implications in Meghalaya, India. ENVIS Bulletin Himalayan Ecology, 24, 87-100.

Peraturan Pemerintah Nomor 26 Tahun 2008 tentang Rencana Tata Ruang Wilayah Nasional Peraturan Daerah Kabupaten Pati Nomor 2 Tahun 2021 tentang Perubahan Peraturan Daerah Kabupaten Pati Nomor 5 Tahun 2011 Tentang Rencana Tata Ruang Wilayah Kabupaten Pati Tahun 2010-2030.

Peraturan Daerah Provinsi Jawa Tengah Nomor 16 Tahun 2019 tentang Perubahan Atas Peraturan Daerah Provinsi Jawa Tengah Nomor 6 Tahun 2010 tentang Rencana Tata Ruang Wilayah Provinsi Jawa Tengah Tahun 2009-2029.

Prayitno, H. T. (2017). Kajian Banjir Bandang di Desa Sukolilo Melalui Tinjauan Peta Sungai. Jurnal Litbang, XIII (1), 13-23.

Ran, J., \& Nedovic-budic, Z. (2016). Integrating Spatial Planning and Flood Risk Management: A New Conceptual Framework for the Spatially Integrated Policy Infrastructure. Computers, Environment and Urban Systems, 57, 68-79. http://doi.org/10.1016/j.compenvurbsys.2016.01.008.

Reed, M. S., Graves, A., Dandy, N., Posthumus, H., Hubacek, K., Morris, J., \& Stringer, L. C. (2009). Who' s in and why? A typology of stakeholder analysis methods for natural resource management. Journal of Environmental Management, 90(5), 1933-1949. http://doi.org/10.1016/j.jenvman.2009.01.001.

Ringo, J. E., \& Mayengo, G. (2016). Effects of Limestone Mining on Deforestation and Land Degradation in Mbeya Region, Tanzania. International Journal of Modern Social Sciences, 5(2), 117-132.

Salam, A., \& Noguchi, T. (2006). Evaluating capacity development for participatory forest management in Bangladesh's Sal forests based on d 4Rs T stakeholder analysis. Forest Policy and Economics, 8, 785-796. http://doi.org/10.1016/j.forpol.2004.12.004.

Tyas, D. N., Vitdiawati, R., \& Nusantari, R. (2016). Konservasi dan Pemanfaatan Berkelanjutan Kawasan Karst Gunung Sewu Sebagai Bagian Geopark untuk Mempertahankan Fungsi Ekologi. Prosiding Symposium on Biology Education, 311324.

Wacana, P., Rodialfallah, A., Chandra, F., Mesah, D., \& Raimon, R. (2011). Study of the Potential of Karst Region in North Kendeng, the Districts of Grobogan and Pati. Proceeding of the Asian Trans-Disciplinary Karst Conference, 1, 169-180. 